\title{
Differential expression of the lethal gene Luteus-Pa in cacao of the Parinari series
}

\author{
B.C. Rehem ${ }^{1}$, A.-A.F. Almeida1, G.S.F. Figueiredo ${ }^{1}$, A.S. Gesteira², S.C. Santos ${ }^{1}$, \\ R.X. Corrêa' ${ }^{1}$ M.M. Yamada ${ }^{3}$ and R.R. Valle ${ }^{3}$ \\ 1Departamento de Ciências Biológicas, Universidade Estadual de Santa Cruz, \\ Ilhéus, BA, Brasil \\ ${ }^{2}$ Empresa Brasileira de Pesquisa Agropecuária, Cruz das Almas, BA, Brasil \\ ${ }^{3}$ Centro de Pesquisas do Cacau, \\ Comissão Executiva do Plano da Lavoura Cacaueira, Itabuna, BA, Brasil \\ Corresponding author: A.-A.F. Almeida \\ E-mail: alexalan.uesc@gmail.com \\ Genet. Mol. Res. 15 (1): gmr.15014925 \\ Received June 2, 2015 \\ Accepted October 20, 2015 \\ Published February 19, 2016 \\ DOI http://dx.doi.org/10.4238/gmr.15014925
}

\begin{abstract}
The recessive lethal character Luteus- $P a$ is found in cacao (Theobroma cacao) genotypes of the Parinari series ( $\mathrm{Pa}$ ) and is characterized by expression of leaf chlorosis and seedling death. Several genotypes of the $\mathrm{Pa}$ series are bearers of the gene responsible for the expression of the Luteus-Pa character, which can be used as a tool for determining relationships between genotypes of this group. To evaluate this phenomenon, we analyzed the differential expression of genes between mutant seedlings and wild-type hybrid $\mathrm{Pa} 30 \times 169$ seedlings, with the aim of elucidating the possible lethal mechanisms of the homozygous recessive character Luteus-Pa. Plant material was harvested from leaves of wild and mutant seedlings at different periods to construct a subtractive library and perform quantitative analysis using real-time PCR. The 649 sequences obtained from the subtractive library had an average length of $500 \mathrm{bp}$, forming 409 contigs. The probable proteins encoded were grouped into 10 functional categories. Data from
\end{abstract}


ESTs identified genes associated with Rubisco, peroxidases, and other proteins and enzymes related to carbon assimilation, respiration, and photosystem 2. Mutant seedlings were characterized by synthesizing defective PsbO and PsbA proteins, which were overexpressed from 15 to 20 days after seedling emergence.

Key words: Gene expression; Lethal factor; Natural mutation; Theobroma cacao

\section{INTRODUCTION}

Molecular biology techniques, particularly those employing whole genome sequencing, have changed the fundamental paradigm of biology. In these techniques, rather than trying to find a protein for a function previously observed, the functions of proteins whose primary sequences are known are investigated (Rebouças and Gomes, 1999). According to these authors, many cellular functions are redundantly performed in the cell. Wright and Dyson (1999) stated that the function of a particular protein depends on the "functional context" where it is inserted. The experimental approaches that analyze a set of proteins, whose expression is modified in a specific functional condition, allow the identification of proteins that express themselves somewhat, or even fail to express (Eisenberg et al., 2000).

For situations of recessive mutations caused by a single gene, where the aim is to evaluate the differential expression among seedlings derived from the same cross, and when $1 / 4$ of the progeny is characterized by a different behavior (Bartley, 2005), the construction of a subtractive library is used (Diatchenko et al., 1996). Messenger RNA is converted into DNA by complementary DNA synthesis (cDNA) using the reverse transcriptase enzyme that synthesizes a polynucleotide sequence complementary to an existing RNA strand (Diatchenko et al., 1996). Once the cDNA is synthesized, the RNA of the hybrid molecule may be partially degraded by treatment with RNAse (Rebrikov et al., 2004). The remaining RNA fragments then serve as primers for DNA-polymerase I, which synthesizes the second cDNA strand, resulting in a DNA fragment that can be connected to a vector and cloned. The resulting cDNA clones are representative of the mRNA present in the original preparation (Diatchenko et al., 1996).

The expressed sequence tags (ESTs) generated by the subtractive library can be compared with genes available in gene data banks (Eisenberg et al., 2000). The results of these comparisons are used as references to determine the probable functions of the cDNA clones. Therefore, specific genes can be selected for further complete studies (Covitz et al., 1998). Proteins or nucleic acids experimentally obtained can also be compared with ESTs available in databases to determine if the cDNA of a particular gene has been cloned (Eisenberg et al., 2000). These methods have led to rapid identification of genes in many organisms, thus accelerating research, since they provide genetic material for further investigation (Covitz et al., 1998).

Research on the compatibility between cacao (Theobroma cacao) genotypes of the Peruvian Parinari $(\mathrm{Pa})$ series, resulting from the reciprocal crosses of some $\mathrm{Pa}$ genotypes (Yamada et al., 1982), corroborated the occurrence of the simple lethal recessive character named Luteus-Pa in the population. This genotypic feature was first identified due to the appearance of 
a physiological trait that caused leaf chlorosis in seedlings of the Pa series, resulting in death of the seedling approximately 30 to 40 days after planting (Almeida et al., 1998). This gene is in heterozygosis in these genotypes, segregating in a 3:1 proportion when crossed or selfed (Bartley, 1969; Bartley et al., 1983). Many of these abnormalities are due to the action of recessive alleles probably originating from individual mutations in specific populations or genotypes, causing the non-pigmentation of leaves (Bartley, 2005). Physiological studies have shown that this gene acts in the reaction center of photosystem 2 (PS 2) (Almeida et al., 1998). Data already obtained that several genotypes of the Pa series bear the factors responsible for expression of the Luteus-Pa character, which can be used as a tool to determine relationships between genotypes of this group (Bartley, 2005).

The Pa series consists of a large number of different genotypes widely used in genetic improvement of populations and formation of hybrid varieties. Additionally, the Luteus-Pa character can be useful in determining individuals in the Pa series, as a potential genetic marker, and as a tool in paternity testing, among others. Because of the importance of this population for cocoa breeding, the aim of this study was to analyze the expression of Luteus-Pa in wild-type and mutant seedlings.

\section{MATERIAL AND METHODS}

\section{Plant material and cultivation conditions}

The experiment was conducted in a greenhouse at the Universidade Estadual de Santa Cruz (UESC), Ilhéus, Bahia, Brazil. The hybrid seeds, resulting from controlled pollination crosses between Pa 30 x Pa 169 at the Germplasm Bank (BAG) of the Centro de Pesquisas do Cacau (CEPEC)/CEPLAC, were germinated in $2 \mathrm{~L}$ capacity polyethylene bags filled with organic substrate (peat and peels of milled Pinus and milled coconut fiber in a 1:1 ratio), enriched by macro- and micronutrients according to the plant requirements (Souza Júnior, 2007).

\section{Identification of mutant and wild-type seedlings}

The identification of mutant and wild-type seedlings was performed by measuring net photosynthetic rate per unit leaf area 15 days after seedling emergence (DAE; Figure 1) and chlorophyll fluorescence emission at the leaf level (Almeida et al., 1998). The measurements were conducted on mature leaves of 12 seedlings for each type (mutant and wild), between 7:30 and 9:30 h, using a Li-6400 portable photosynthesis system (Li-Cor, Lincoln, NE, USA) equipped with an artificial light source 6400-02B RedBlue. The equipment was adjusted to a photosynthetic photon flux density (irradiance) of $800 \mu \mathrm{mol}$ photons $\cdot \mathrm{m}^{-2} \cdot \mathrm{s}^{-1}$, above the light saturation irradiance needed for cacao photosynthesis. Net photosynthetic rate per unit leaf area was estimated from atmospheric $\mathrm{CO}_{2}$ and air humidity values measured inside the chamber (von Caemmerer and Farquhar, 1981). To assess chlorophyll fluorescence in dark-acclimated leaves, a clip was placed on each leaf for $30 \mathrm{~min}$ to reflect solar radiation, decrease leaf temperature, and oxidize the entire photosynthetic electron transport system. Using the fluorescence meter accessory of the LI 6400 photosynthesis system, the minimal $(\mathrm{Fo})$ and maximal $(\mathrm{Fm})$ fluorescence, and the maximum quantum yield ( $\mathrm{Fv} / \mathrm{Fm})$ of PS 2 were measured and recorded (Figure 1) (Maxwell and Johnson, 2000). 


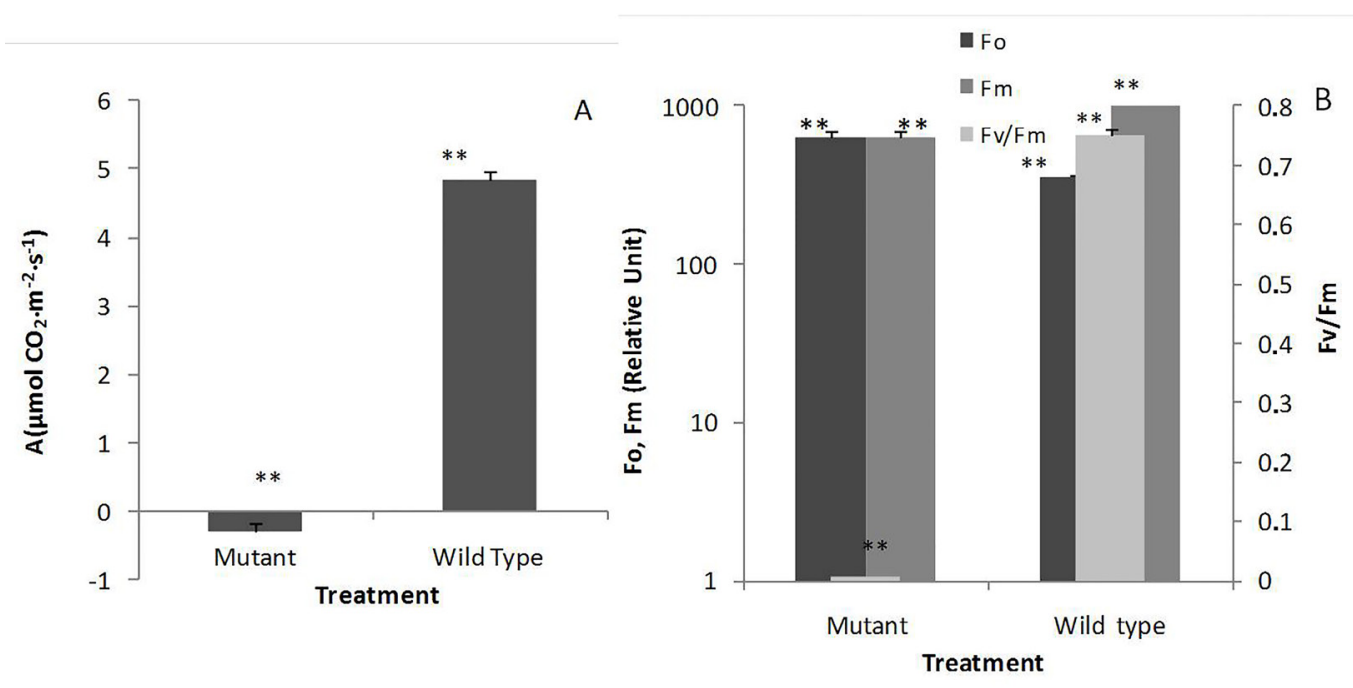

Figure 1. Variables of (A) net photosynthesis (per unit leaf area) and (B) leaf chlorophyll fluorescence emission of wildtype and mutant Theobroma cacao seedlings of the Parinari series 15 days after emergence.

\section{RNA extraction and construction of subtractive library}

Leaves of wild and mutant seedlings were collected at regular intervals of 5 days, starting 15 DAE until the death of the mutant seedlings. The samples were stored at $-80^{\circ} \mathrm{C}$ after fixation in liquid nitrogen, and then lyophilized. RNA was extracted from leaves of the progenies at four different periods $(15,20,25$, and $30 \mathrm{DAE})$, according to the method of Gesteira et al. (2003), with some modifications. RNA was then treated with DNase and RNase inhibitors. The RNA was evaluated using electrophoresis on a $2 \%$ agarose gel to determine whether the RNA was free from DNA and was intact to undergo the first-strand synthesis reaction, which was used in the construction of the subtractive library. Total RNA from different periods was mixed and used to construct the subtractive library. To construct the library, a PCR-Select ${ }^{\mathrm{TM}}$ CDNA Subtraction kit was used, as described by the manufacturer (Clontech, Clontech Laboratories, Inc., Mountain View, CA, USA). cDNA was cloned into the plasmid pTz57-RT, and electroporated into competent Electromax $10 \beta$ (Invitrogen) cells using a MicroPulse Electroporator (BioRad). The clones were plated on LBagar containing ampicillin $(100 \mu \mathrm{g} / \mathrm{L}), 4 \mu \mathrm{L}$ IPTG $(200 \mathrm{mg} / \mathrm{L})$, and $80 \mu \mathrm{L}$ X-Gal. Selected clones containing the insert were transferred to 96-well microplates, containing LB-agar medium with ampicillin (100 mg/L). After a 14-h growth period, glycerol at $16 \%$ was added, and the stock of clones was stored at $-80^{\circ} \mathrm{C}$.

\section{Plasmid minipreps and sequencing of the subtractive library}

Plasmidial DNA was obtained from individual clones using the alkaline lyses procedure (Sambrook et al., 1989), adapted for 96-well microplates. The bacterial colonies containing the recombinant plasmid were grown on solid medium on $100-\mathrm{mm}$ Petri plates with the appropriate antibiotic. The plating of the colonies was done to obtain a density ranging from the 100 to 150 positive colonies per plate. To check the quality and quantity of plasmidial DNA, samples were electrophoresed on a $2 \%$ 
agarose gel stained with ethidium bromide. The gel was then visualized in a UV transilluminator (Vilber Loumart) and photographed in the photo-documentation system EDAS-290 (Kodak).

The sequencing reactions were performed using the Big DYE sequencing kit (ABI 3100, Applied Biosystems) and the forward primer M13-F 5'-GTAAAACGACGGCCAGT-3'. DNA was sequenced on an ABI-3100 (Applied Biosystems) capillary sequencer. The electropherograms containing sequences were edited to remove the vector using the Lasergene software (Seqman), and only sequences longer than $90 \mathrm{bp}$ were considered. The electropherograms were analyzed using bioinformatic programs to validate their quality for constructing the library. Each edited EST was translated in all 6 ORFs and compared with the NCBI database using the tBLASTx and BLASTx (http://www.ncbi.nlm.nih.gov/BLAST/), and the BLAST 2 GO software. The alignments were considered significant when the expected value for similarity was lower than $1 \times 10^{-6}$. The provable EST similarities were annotated based on the search results of BLAST 2 GO and gene ontology information (http://www.geneontology.org/).

\section{Real-time PCR}

Leaves of wild and mutant seedlings were sampled at 5-day intervals, beginning 5 DAE (the period in which the seedlings have already emitted the first pair of cotyledonary leaves), until the death of the mutant seedlings. The samples were stored at $-80^{\circ} \mathrm{C}$ following fixation in liquid nitrogen, and then lyophilized. RNA was extracted from leaves of wild and mutant seedlings at six different periods $(5,10,15,20,25$, and 30 DAE) using the ZR Plant RNA miniprep kit (Zymo Research), and treated with RNase inhibitor. RNA purity and integrity was assessed by electrophoresis on a $1 \%$ agarose gel. The RNA samples were used for cDNA synthesis using the SuperScript ${ }^{\mathrm{TM}}$ II RNase H-Reverse Transcriptase kit (Invitrogen, Life Technologies, São Paulo, SP, Brazil), according to the manufacturer protocol, using oligo $\mathrm{d}(\mathrm{T}) 15$ primers. The reactions were incubated at $42^{\circ} \mathrm{C}$ for $30 \mathrm{~min}, 50^{\circ} \mathrm{C}$ for $40 \mathrm{~min}$, and $95^{\circ} \mathrm{C}$ for $5 \mathrm{~min}$.

Quantitative RT-PCR was performed in a real-time PCR thermocycler (Applied Biosystems, model 7500) using detection sequence (fluorophore) non-specific SYBR Green I (Fermentas, Life Technologies). The high number of transcripts of proteins PsbO and PsbA was analyzed using specific primers (Table 1). To test the quality of these primers and the specificity and identity of the reverse transcription products, the RT-PCR products were monitored after each PCR cycle, using a curve analysis of reaction products capable of distinguishing PCR gene-specific products from non-gene-specific products. The temperature of PCR products was raised from $55^{\circ}$ to $99^{\circ} \mathrm{C}$ at a rate of $1^{\circ} \mathrm{C} / 5 \mathrm{~s}$, and the resulting data were analyzed using the LightCycler software. Only a single band with a characteristic melting point was observed for each sample, indicating that the RT-PCR produced a specific product for the primers used. To confirm that the RT-sqPCR produced only genes of interest, the PCR products were separated and visualized on a $1 \%$ agarose gel.

The following cycling conditions were used for cDNA synthesis: 1 cycle at $50^{\circ} \mathrm{C}$ for 2 min, 1 cycle at $95^{\circ} \mathrm{C}$ for $10 \mathrm{~min}$ and 50 cycles at $50^{\circ} \mathrm{C}$ for $60 \mathrm{~s}$ to anneal the primers. The reaction mix consisted of: cDNA template, $0.5 \mu \mathrm{M}$ each primer and a sufficient amount of fluorophore SYBR Green I (Fermentas) in a final reaction volume of $25 \mu \mathrm{M}$.

Threshold cycle $(\mathrm{Ct})$ values were determined using the LightCycler software. Numbers for the relative expression of genes were calculated as a percentage of the wild seedlings, using the $2^{-\Delta \Delta C t}$ method (Livak and Schmittgen, 2001) and ubiquitin as an endogenous control in order to detect changes in transcript number (Table 1). 
Table 1. Pairs of gene-specific primers used in the RT-sqPCR analyses.

\begin{tabular}{l|l}
\hline Gene & Primer \\
\hline PsbO & Forward: 5'-GCAAACGCTGAAGGAGTT-3' \\
& Reverse: 5'-GGCTTGAAGGCAATGAGTC-3' \\
\hline PsbA & Forward: 5'-GGTTTGCACTTTTACCCGA-3' \\
\hline Ubiquitin & Reverse: 5'-CTCATAAGGACCGCATT-3' \\
\hline & Forward: 5'-AGTAGATGACTGGATTGGAGGT-3' \\
& Reverse: 5'-GAGTATCAAAACAAAAGCATCG-3' \\
\hline
\end{tabular}

\section{Statistical analysis}

For the construction of the subtractive library, the experiment was arranged in a completely randomized design with eight treatments consisting of wild and mutant seedlings and four harvest dates of plant material $(15,20,25$, and 30 DAE seedling), five replicates, and one seedling per experimental unit. For the RT-sqPCR data analyses, a completely randomized design was also used with 12 treatments consisting of wild and mutant seedlings and six harvest dates of plant material $(5,10,15,20,25$, and $30 \mathrm{DAE})$, with three replicates and three biological replicates (concentrated RNA was diluted three times to a concentration of $500 \mathrm{ng}$ ) for each specific primer evaluated (PsbO and PsbA).

\section{RESULTS}

Within $15 \mathrm{DAE}$, expression of the lethal gene Luteus-Pa was observed in $1 / 4$ of the progenies resulting from the cross of $\mathrm{Pa} 30 \times \mathrm{Pa} 169$ (wild-type), thus, segregating in a 3:1 ratio (Figure 2). The leaves of seedlings carrying the lethal allele suffered chlorosis and exhibited necrotic spots followed by seedling death at 60 DAE (Figure 2), after the exhaustion of cotyledonary reserves.

RNA extracted at different times was mixed into two pools, one containing only the genetic material of wild-type seedlings and the other from the mutant seedlings. RNA samples of each pool were used to synthesize the first-strand of cDNA used in the construction of a subtractive library. During the construction of the library, cDNA strands, enriched to full length, were run on agarose gels at $2 \%$, in which a smear was observed, indicative of the variety of fragment sizes of cDNA (Figure 3). The cDNA libraries of wild and mutant seedlings were then purified for small contaminants, such as salts, solvents, enzymes, nucleotides, proteins, polysaccharides, metabolites, and other minor nucleic acids using columns used to purify RNA (CHROMA SPIN-1000 Clontech) (Figure 4).

The cDNA libraries of both progenies were digested with Rsal, linked afterwards, and then subjected to the subtraction reaction to isolate genes that were differentially expressed as a function of the expression of the lethal gene (Figure 5). PCR of colonies, to confirm the cloning of cDNAs into the vector pTz57-RT, showed bands with sizes ranging from 1000 to $1500 \mathrm{~kb}$ (Figure 6).

The sequences originating from the subtractive library of wild and mutant Parinari seedlings showed an average length of $500 \mathrm{bp}$ with satisfactory expected distribution values (e-value; Figure 7). From the 1152 sequences cloned, 649 sequences met the quality criteria adopted after elimination of the vector, nucleotide fragments, and sequences shorter than $90 \mathrm{bp}$. The length of these sequences varied from 100 to $1200 \mathrm{bp}$. In the 649 ESTs, 409 contigs were obtained, of which 237 showed significant homology to genes identified and deposited in the NCBI database. The remaining 172 contigs had no similarity with any available genes. Some of the contigs with a higher EST number showed similarity to i) proteins of PS 2 (42 ESTs), ii) 60S ribosomal proteins (12 ESTs), iii) reverse transcriptase (9 ESTs), iv) heat shock proteins (9 ESTs), v) Rubisco (8 ESTs), 
vi) ATP synthase (8 ESTs), vii) NADH dehydrogenase (8 ESTs), and viii) trypsin inhibitor (6 ESTs) (Table 2). The likely encoded proteins were grouped into 10 functional categories according to the classification described by Covitz et al. (1998).
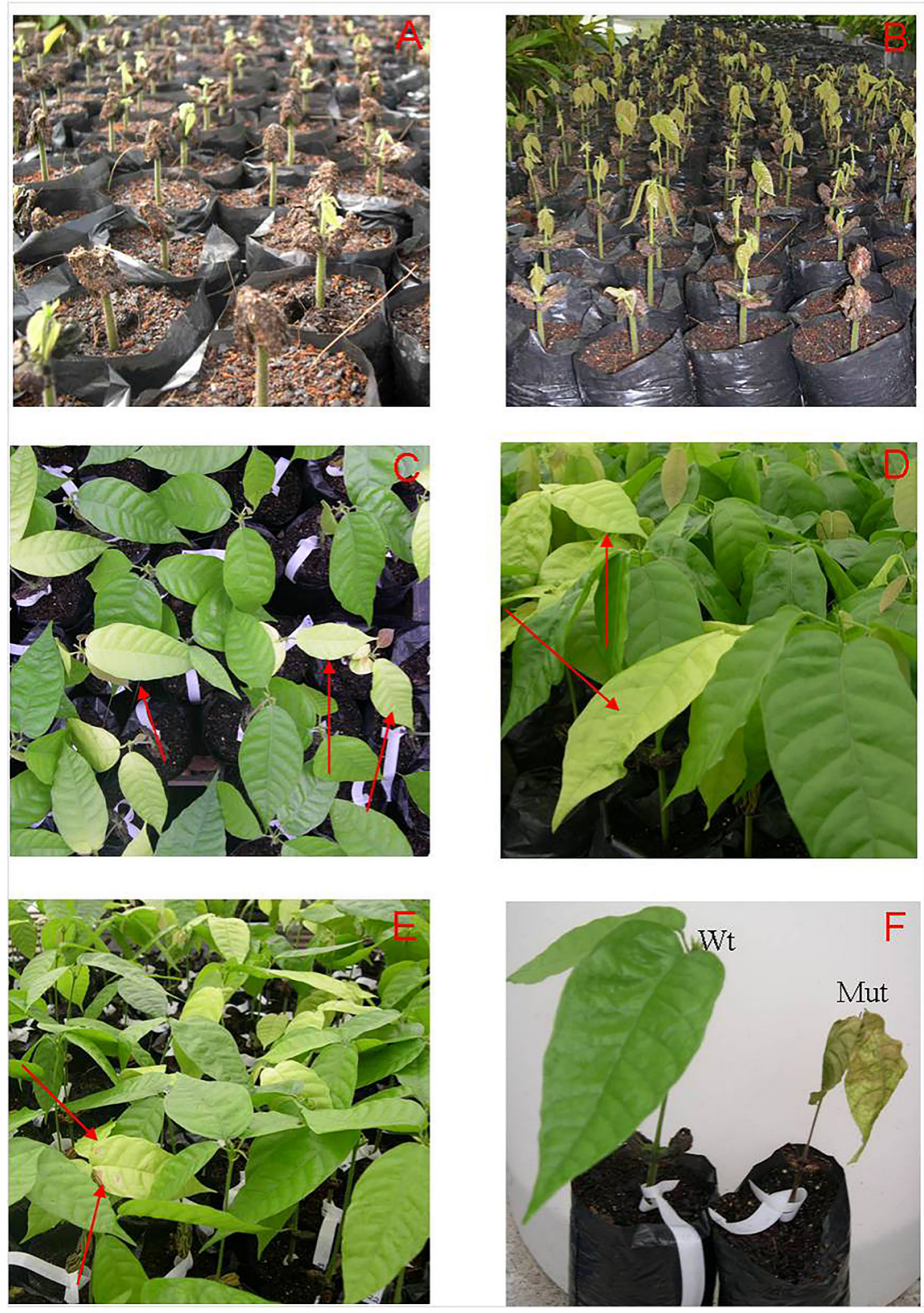

Figure 2. Mutant and wild-type seedlings of the Pa 30 x Pa 169 hybrid at 5 (A), 10 (B), 15 (C), 20 (D), 25 (E), and 30 (F) days after emergence. Note the leaf chlorosis in the mutant seedlings ( $C$ and $D$, red arrows), followed by necrotic points in the leaf (E, red arrows) and seedling death $(F)$. 


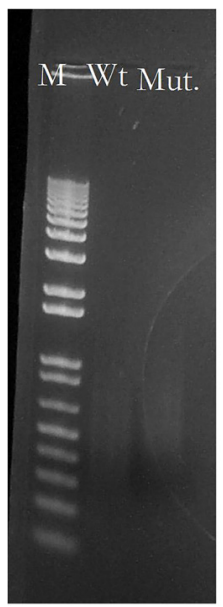

Figure 3. Migration pattern of cDNA of the 2 nd strand on a $2 \%$ agarose gel. Lane $M=$ size marker fragment $1000 \mathrm{bp}$; $\mathrm{Wt}=\mathrm{cDNA}$ of wild-type seedlings; Mut $=\mathrm{cDNA}$ of mutant seedlings.

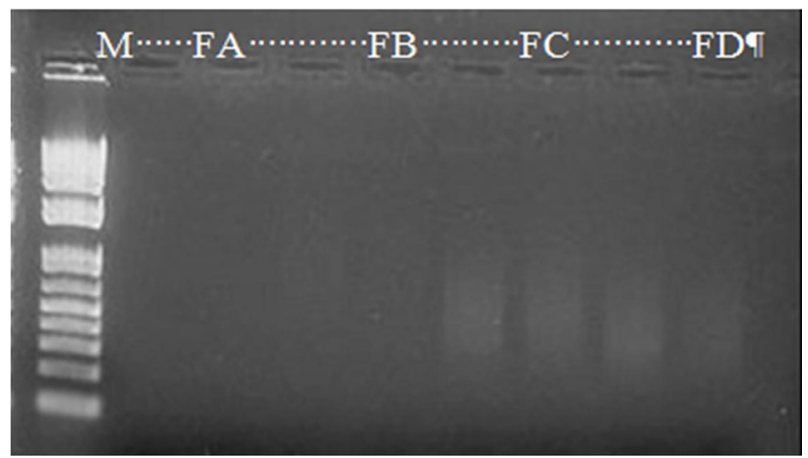

Figure 4. Fractionation by size of $\mathrm{CDNA}$ on $2 \%$ agarose gel. $\mathrm{FA}=$ fraction $\mathrm{A} ; \mathrm{FB}=$ fraction $\mathrm{B} ; \mathrm{FC}=$ fraction $\mathrm{C}$; and FD $=$ fraction $\mathrm{D}$ (used in construction of subtractive library).
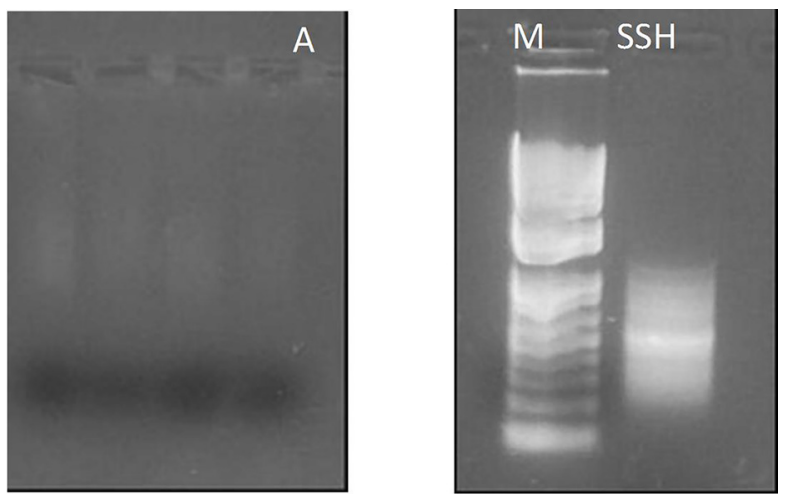

Figure 5. Evaluation of the subtractive library construction on a $2 \%$ agarose gel. (A) Digestion and (B) subtraction. Lane $M=$ marker fragment size $1000 \mathrm{bp}$. SSH = subtractive library. 


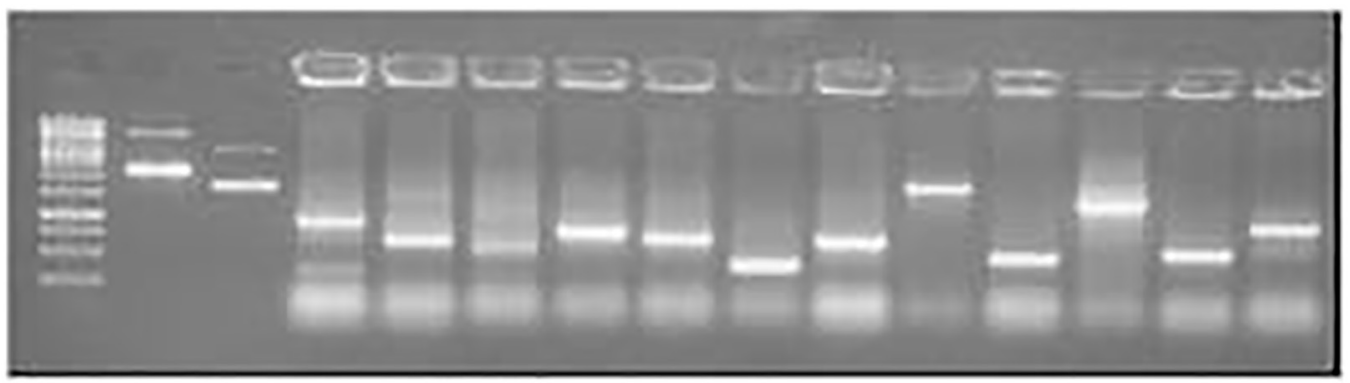

Figure 6. Colony PCR amplification with M13 forward and reverse primers, observed on a $1 \%$ agarose gel.

Table 2. Probable identification of generated ESTs grouped into 10 functional classes.

\begin{tabular}{|c|c|}
\hline Class & Functional annotation \\
\hline Structures of the cellular wall or metabolism & $\begin{array}{l}\text { Hydrolase associated with the cellular wall } \\
\text { Precursor of the protein expansin }\end{array}$ \\
\hline Cytoskeleton & Actin pmi 1 \\
\hline Membrane transport & $\begin{array}{l}\text { H+ ATPase exporter } \\
\text { Gama } 1 \\
\text { Amino acid transport } \\
\text { Transporter of two sections of } \mathrm{H}+\text { ATPase }\end{array}$ \\
\hline Signal transduction & $\begin{array}{l}\text { Protein } 3 \text { and } 4 \text { phosphatidylinositol kinase } \\
\text { Protein kinase }\end{array}$ \\
\hline Hormone metabolism and secondary & $\begin{array}{l}\text { Ethylene responsive element binding factor } 2 \\
1 \text { Fragment of the protein induced by salicylic acid } \\
\text { Glutathione } S \text {-transferase } \\
\text { Nonspecific monooxygenase } \\
\text { Protein induced by salicylic acid }\end{array}$ \\
\hline Primary metabolism & $\begin{array}{l}\text { Acetyl-CoA carboxylase } \\
\text { CP43 chlorophyll apoprotein of photosystem II } \\
\text { P700 apoprotein of photosystem I } \\
\text { ATP synthase } \\
\text { Cytochrome b6 } \\
\text { Complex iron-sulfur cytochrome b6 } \\
\text { Proteins group of photosystem I } \\
\text { Glyceraldehyde 3-phosphate dehydrogenase } \\
\text { Hexokinase } 1 \\
\text { NADH dehydrogenase } \\
\text { Precursor of the protein p carboxylase of the complex glycine } \\
\text { decarboxylase } \\
\text { Cp43 protein of photosystem II } \\
\text { D1 protein of photosystem II } \\
\text { L protein of photosystem II } \\
\text { M protein of photosystem II } \\
\text { Z protein of photosystem II } \\
\text { Protein of photosystem I } \\
\text { ycf3 protein of photosystem I } \\
\text { S-adenosylmethionine decarboxylase } \\
\text { Tryptophan synthase } \\
\text { III subgroup of the glutaredoxin } \\
\alpha \text { subunit of cytochrome b559 of photosystem II } \\
\beta \text { subunit of ATP synthase } \\
\beta \text { subunit of Acetyl carboxylase carboxyltransferase } \\
\beta \text { subunit of carboxyltransferase } \\
\text { D subunit of NADH dehydrogenase } \\
\text { ICf0 subunit of ATP synthase } \\
\text { Larger subunit of ribulose } 1,5 \text {-bisphosphate carboxylase/oxygenase } \\
\text { Smaller subunit of ribulose } 1,5 \text {-bisphosphate carboxylase /oxygenase } \\
\text { Psak subunit of the reaction center of photosystemI }\end{array}$ \\
\hline
\end{tabular}

Continued on next page 


\begin{tabular}{|c|c|}
\hline \multirow[t]{2}{*}{ Class } & Functional annotation \\
\hline & $\begin{array}{l}\text { IV subunit of NADH Plastoquinone oxidoreductase } \\
\text { IV subunit of NADH dehydrogenase } \\
\text { IV subunit of complex cytochrome b6f } \\
\text { Cytochrome f }\end{array}$ \\
\hline Gene expression and RNA metabolism & $\begin{array}{l}\text { Protein RNA binding } \\
\alpha \text { subunit of RNA polymerase } \\
\text { Transcriptase reverse }\end{array}$ \\
\hline Synthesis and protein processing & $\begin{array}{l}\text { Chaperone } \\
\text { Trypsin inhibitor } \\
\text { Trypsin } 21 \mathrm{kDa} \\
\text { Small protein of shock thermal class II } \\
\text { Small protein of shock thermal class II cytosolic } \\
\text { Small protein of shock thermal } 3 \mathrm{~b} \text { class I cytosolic } \\
\text { Protein of thermal shock of low molecular weight } \\
\text { Protein of thermal shock } \\
\text { Protein of thermal shock of } 18 \mathrm{kDa} \\
\text { Protein of thermal shock } 21 \\
\text { Protein of thermal shock } 90 \\
\text { Protein ubiquitin ligase } \\
\text { Mitochondrial protein of thermal shock } \\
\text { Mitochondrial protein of thermal shock } 22 \mathrm{kDa}\end{array}$ \\
\hline Defense & $\begin{array}{l}\text { Ribosomal protein I12 } \\
\text { Ribosomal protein I14 } \\
\text { Ribosomal protein } \mathrm{s} 7 \\
\text { Ribosomal protein s8 } \\
60 \text { S subunit of ribosomal RNA } \\
\text { Ubiquitin } 12 \\
\text { Peroxidase } \\
\text { Catalase }\end{array}$ \\
\hline Others & $\begin{array}{l}\text { Carboxylesterase cxe } \\
\text { Glutaredoxin } \\
\text { Abundant protein of the late embryogenesis } \\
\text { ORF protein 54b Pinus thunbergii } \\
\text { ORF protein } 61 \mathrm{c} \text { Pinus koraiensis } \\
\text { ORF protein 124 Pinus koraiensis } \\
\text { Lac repressing }\end{array}$ \\
\hline
\end{tabular}

The ESTs observed here showed special homology to genes of Vitis vinifera and other species belonging to the genus Theobroma (Figure 8). Transcript levels were evaluated using realtime quantitative PCR (RT-sqPCR) using RNA isolated from leaves of wild and mutant seedlings at different periods. The lethal gene Luteus-Pa induced high expression of the protein PsbO at 15 and 20 DAE and PsbA at 15, 20, and 25 DAE in mutant seedlings compared to the wild type (Figure 9). This period coincided with the lethal factor expression that results in photosynthesis inhibition, indicating that proteins PsbO and PsbA have roles within PS 2.

At 5 and $10 \mathrm{DAE}$, no differences were observed between the evaluated seedlings because there was no expression of the lethal factor Luteus-Pa among mutants at this stage. At $30 \mathrm{DAE}$, there was a decrease in the expression of both proteins in the mutant seedlings (Figure 9).

\section{DISCUSSION}

We observed a large number of proteins linked to PS 1 and PS 2, contrary to the results observed in the expression library of T. cacao constructed by Gesteira et al. (2003), which is considered a standard for such analysis. 


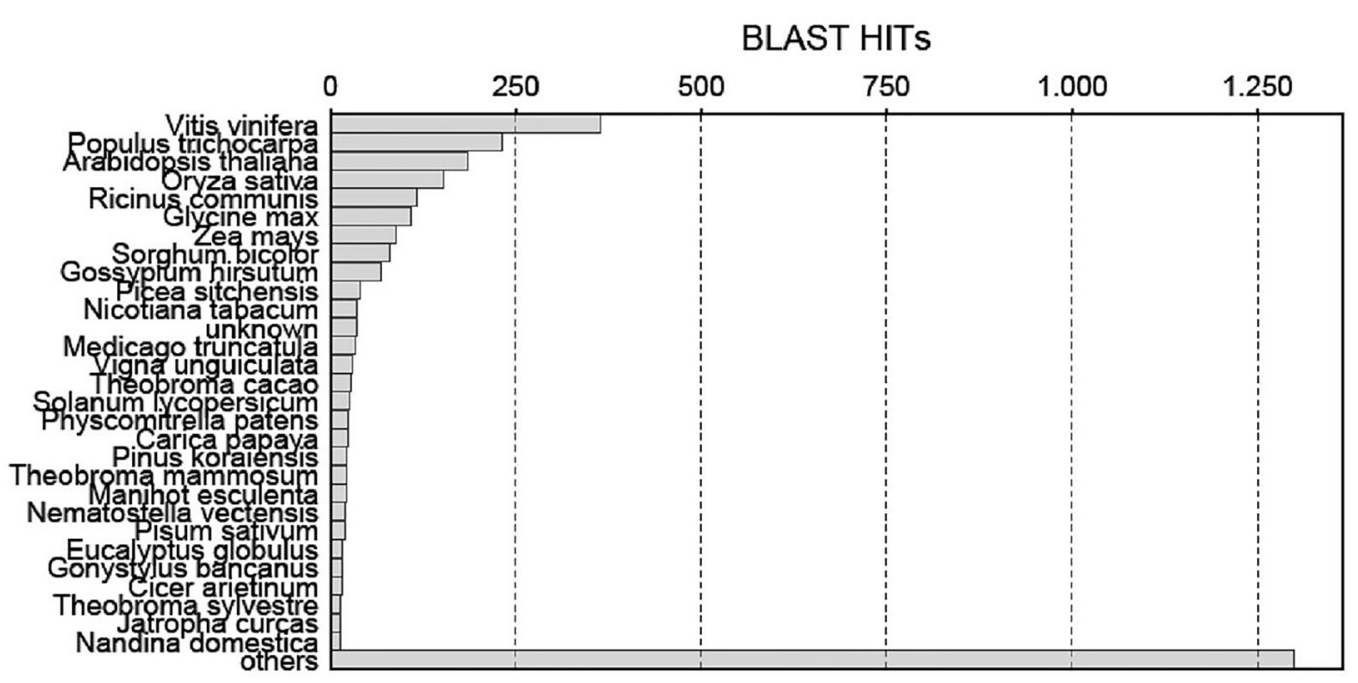

Figure 8. Distribution of plant species ESTs from a subtractive library of a progeny of Theobroma cacao of the Parinari series that showed homology.
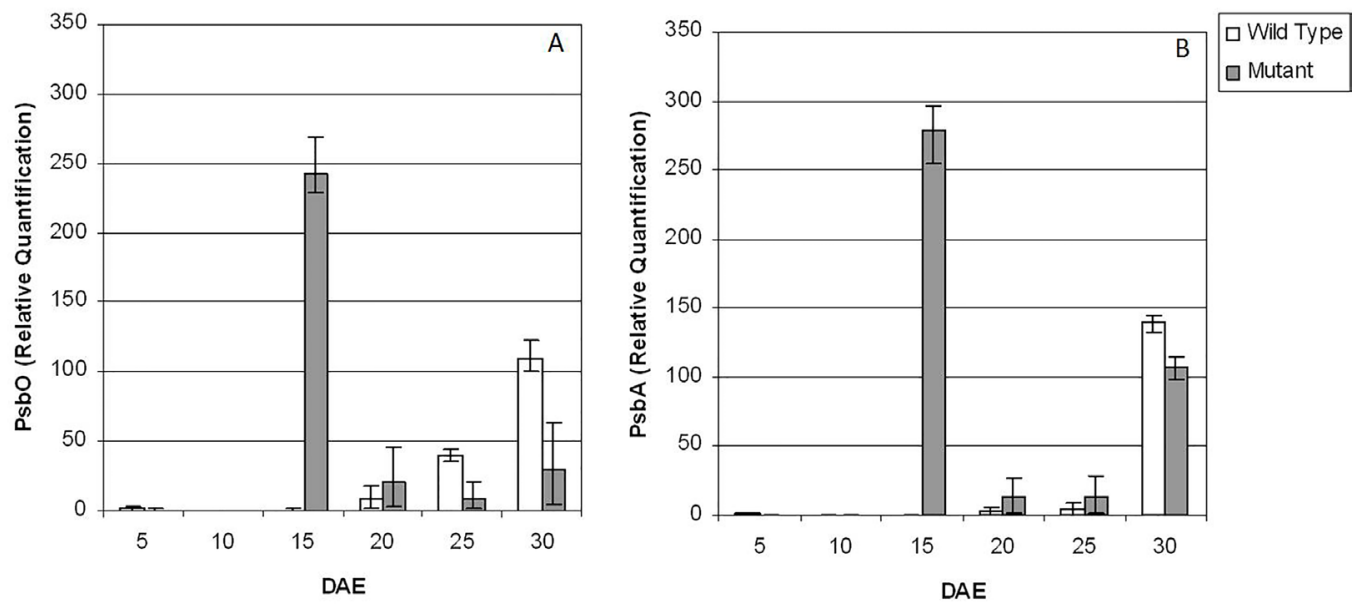

Figure 9. Amount of transcripts encoded by the gene-linked proteins PsbO (A) and PsbA (B) quantified by RT-sqPCR transcripts and normalized by ubiquitin in wild-type and mutant of Theobroma cacao seedlings of the Parinari series grown for 30 days after emergence (DAE). Values are reported relative to the seedlings of the wild type compared with the mutant seedlings. The means represent three replications $\pm \mathrm{SE}$ and three biological replicates.

The categories in which genes were predominant were primary metabolism and synthesis and processing of proteins (Table 2). The diverse representations of genes coding for proteins related to cell wall synthesis, cytoskeleton, and other active processes during growth were expected as they reflect the active growth stage of the tissue used in the library construction (Covitz et al., 1998; Zhang et al., 2001). Given the possible involvement in adaptation mechanisms of the mutant seedlings to the stress caused by the Luteus-Pa, genes categorized in defensive functions may be appropriate targets to study. 
Among the most abundant ESTs, there were 42 that exhibited similarity to genes that encode PS 2 proteins, characterized in V. vinifera (Figure 8). The expression of these genes presumes a strategy adopted by the mutant seedlings of $\mathrm{Pa}$ to survive the conditions of electron transport blockage at the PS 2 level in the photochemical phase of photosynthesis (Almeida et al., 1998).

Other genes highly expressed in T. cacao leaves were related to Rubisco, ATP synthase, NADH dehydrogenase, ribosomal proteins, reverse transcriptase, and heat-shock stress (Gesteira et al., 2003). Rubisco has a high molecular weight and simultaneously presents two functions: it catalyzes the carboxylation and the oxygenation of pentose ribulose-1,5-bisphosphate (RuBP), a central molecule used in carbon fixation by living organisms (Aragão et al., 2005). The first function assigns Rubisco the main role in the photosynthetic process and, in contrast, it also has a role in initiating photorespiration (Spreitzer and Salvucci, 2002).

$\mathrm{NADH}$ dehydrogenases are components of the mitochondrial membrane and are directly involved in electron transport in the respiratory chain, playing a key role in providing energy to cells (Heldt, 2005). Both ATP synthase and NADH dehydrogenase occur in several plant cells, in different molecular forms. They catalyze the same reaction even though differences may occur in the composition of amino acid sequences affecting the catalytic properties and the enzyme activity (Casagrande et al., 2001).

Ribosomal proteins are important for maintaining the stability and integrity of the ribosome. In addition, the 60S subunit of ribosomal RNA plays a key role, together with the $40 \mathrm{~S}$ ribosomal subunit, in the selection of signals for initiating translation. Therefore, problems at the translational level result in damage in the synthesis of certain proteins (Heldt, 2005).

Reverse transcriptase polymerizes DNA molecules from RNA molecules, the opposite of what usually occurs in cells, where RNA is produced from DNA (Diatchenko et al., 1996). The fact that some of the contigs with high EST numbers are related to this enzyme demonstrates that the lethal factor Luteus-Pa acts at the transcriptional level.

Under stress conditions, important proteins associated with cellular stress are produced (heat-shock proteins), and these can be induced by both biotic and abiotic stress factors (Lipka and Panstruga, 2005), as in the present study. Mutant seedlings were exposed to a biotic stress caused by the lethal factor Luteus-Pa. Heat-shock proteins belong to a class of molecular chaperones responsible for the correct folding of other synthesized proteins to prevent protein aggregation. These proteins are highly conserved, which suggests their evolutionary importance. Several studies support the theory that heat-shock and/or oxidative stress induce responses both in prokaryotes and eukaryotes. These stresses stimulate the production of reactive oxygen species, which have a key role in inducing the production of molecular chaperones (Muniz, 2006). Little is known about the exact role of heat-shock proteins in plants; however, recent studies have shown that some chaperones are related to the plant's defensive system, acting both in hypersensitive responses and in systemic acquired resistance (Lipka and Panstruga, 2005).

$\mathrm{PsbO}$ is characterized by i) being essential for the efficient and stable evolution of oxygen, ii) being a limiting factor for photosynthesis and growth, and iii) interfering in the concentration of other proteins, such as PsbA (Murakami et al., 2005). According to Nelson and Yocum (2006), PsbA provides ligands for the cofactors and inorganic ions that catalyze the oxidation of water and transfers electrons to PS 2 during the photosynthesis photochemistry phase. Liu et al. (2007) showed that artificial mutants of Arabidopsis thaliana are characterized by having two genes that express two PsbO proteins (PsbO-1 and PsbO-2). These authors also demonstrated that the PsbOs 
are related to the efficiency of the photochemical phase of PS 2 and to the D1 protein of the PS 2 reaction center. Due to the important metabolic roles of PsbO and PsbA, the defective occurrence of such proteins leads to the phenomenon observed in the cacao mutants of the Pa series, which was characterized by a blockage in the photosynthetic electron transport chain, leading to inhibition of photosynthesis in the seedlings. A regulatory protein can repress gene expression. In this case, the gene is inactivated when the protein is linked to controlling sequences or, the protein may play a positive or supporting role in activating or increasing the expression of its target gene (Brown, 2003).

In summary, the EST data obtained by the construction of the subtractive library of wildtype and mutant cacao seedlings of the $\mathrm{Pa}$ series identified genes associated with Rubisco, peroxidases, and other proteins and enzymes related to carbon assimilation, oxidative stress, respiration, and PS 2 of the photosynthetic photochemical phase. The mutant seedlings were characterized by defectively synthesizing PsbO and PsbA, resulting in higher expression of these proteins, especially at 15 and 20 DAE. This event coincided with the period in which the cotyledonary reserves are low and the senescence process begins. These data suggest that the lethal factor promotes the synthesis of defective PsbO and PsbA proteins and, as a consequence, the mutant seedlings respond by increasing their synthesis in an attempt to produce non-defective proteins and activate mechanisms to reduce the damage caused by Luteus-Pa.

\section{ACKNOWLEDGMENTS}

The authors are thankful to Ivanildes Conceição dos Santos, Antônio Carlos, Kleber Alves Gomes, and Vânia Lima Souza for their collaboration during the execution of this study, to Dr. Karina Peres Gramacho and Lívia Santos Lima Lemos for their assistance in the sequencing of the subtractive library, to Universidade Estadual de Santa Cruz (UESC), Comissão Executiva do Plano da Lavoura Cacaueira (CEPLAC) for support, Fundação de Amparo à Pesquisa do Estado da Bahia (FAPESB) and CAPES for granting a PhD scholarship and funding the project.

\section{REFERENCES}

Almeida A-AF, Valle RR and Minar PS (1998). Photosynthesis and associated metabolism during development of a Theobroma cacao hybrid with the lethal factor Luteus-Pa. Photosynthetica 35: 47-60.

Aragão MEF, Guedes MM, Otoch MLO, Guedes MIF, et al. (2005). Differential responses of ribulose-1,5-bisphosphate carboxylase/oxygenase activities of two Vigna unguiculata cultivars to salt stress. Braz. J. Plant. Phys. 17: 207-212. http://dx.doi.org/10.1590/S1677-04202005000200003

Bartley BGD (1969). Selfing of self-incompatible trees. Ann. Rep. Cacao Res. Trinidad, 1969: 22-23.

Bartley BGD (2005). The genetics of the Diversity. In: The genetic diversity of cacao and its utilization. CABI Publishing, Oxfordshire, 279-297.

Bartley BGD, Yamada MM, Castro GCT and Melo GRP (1983). Genetics of Theobrama cacao: occurrence of lethal factor 'Luteus - Pa' in family Parinari. Theobroma 13: 275-278

Brown TA (2003). Clonagem Gênica e Análise de DNA: Uma introdução. $4^{a}$ edn. ArtMed: Porto Alegre.

Casagrande EC, Farias JRB, Neumaier N, Oya T, et al. (2001). Expressão gênica diferencial durante déficit hídrico em soja. Rev. Bras. Fisiol. Veg. 13: 168-184. http://dx.doi.org/10.1590/S0103-31312001000200006

Covitz PA, Smith LS and Long SR (1998). Expressed sequence tags from a root-hair-enriched Medicago truncatula cDNA library. Plant Physiol. 117: 1325-1332. http://dx.doi.org/10.1104/pp.117.4.1325

Diatchenko L, Lau YF, Campbell AP, Chenchik A, et al. (1996). Suppression subtractive hybridization: a method for generating differentially regulated or tissue-specific cDNA probes and libraries. Proc. Natl. Acad. Sci. U. S. A. 93: 6025-6030. http:// dx.doi.org/10.1073/pnas.93.12.6025

Eisenberg D, Marcotte EM, Xenarios I and Yeates TO (2000). Protein function in the post-genomic era. Nature 405: 823-826. 
http://dx.doi.org/10.1038/35015694

Gesteira AS, Michelli F, Ferreira CF and Cascardo JC (2003). Isolation and purification of functional total RNA from different organs of cacao tree during its interaction with the pathogen Crinipellis perniciosa. Biotechniques 35: 494-496.

Heldt HW (2005). Plant Biochemistry. 3rd edn. Elsevier Academic Press, San Diego, California.

Lipka V and Panstruga R (2005). Dynamic cellular responses in plant-microbe interactions. Curr. Opin. Plant Biol. 8: 625-631. http://dx.doi.org/10.1016/j.pbi.2005.09.006

Liu H, Frankel LK and Bricker TM (2007). Functional analysis of photosystem II in a PsbO-1-deficient mutant in Arabidopsis thaliana. Biochemistry 46: 7607-7613. http://dx.doi.org/10.1021/bi700107w

Livak KJ and Schmittgen TD (2001). Analysis of relative gene expression data using real-time quantitative PCR and the $2^{-\Delta \Delta C t}$ method. Methods 25: 402-408. http://dx.doi.org/10.1006/meth.2001.1262

Maxwell K and Johnson GN (2000). Chlorophyll fluorescence - a practical guide. J. Exp. Bot. 51: 659-668. http://dx.doi. org/10.1093/jexbot/51.345.659

Muniz CR (2006). Análise da resposta a estresse oxidativo de Xylella fastidiosa através de hibridações de microarranjos de DNA. Dissertação de mestrado. Programa de Pós Graduação Interunidades em Biotecnologia da Universidade de São Paulo-ICB/IPT/Butantan.

Murakami R, Ifuku K, Takabayashi A, Shikanai T, et al. (2005). Functional dissection of two Arabidopsis PsbO proteins: PsbO1 and PsbO2. FEBS J. 272: 2165-2175. http://dx.doi.org/10.1111/j.1742-4658.2005.04636.x

Nelson N and Yocum CF (2006). Structure and function of photosystems I and II. Annu. Rev. Plant Biol. 57: 521-565. http:// dx.doi.org/10.1146/annurev.arplant.57.032905.105350

Rebouças NA and Gomes MD (1999). Hibridização subtrativa seguida de PCR. Biotecnol. Cienc. Desenv. 30-35.

Rebrikov DV, Desai SM, Siebert PD and Lukyanov SA (2004). Suppression subtractive hybridization. Methods Mol. Biol. 258: 107-134.

Sambrook J, Fritsch EF and Maniatis T (1989). Molecular Cloning: A Laboratory Manual. 2nd edn. Cold Spring Harbor Press, New York.

Souza Júnior JO (2007). Substratos e adubação para mudas clonais de cacaueiro. PhD thesis, Universidade de São Paulo, São Paulo, Brasil.

Spreitzer RJ and Salvucci ME (2002). Rubisco: structure, regulatory interactions, and possibilities for a better enzyme. Annu. Rev. Plant Biol. 53: 449-475. http://dx.doi.org/10.1146/annurev.arplant.53.100301.135233

von Caemmerer S and Farquhar GD (1981). Some relationships between the biochemistry of photosynthesis and the gas exchange of leaves. Planta 153: 376-387. http://dx.doi.org/10.1007/BF00384257

Wright PE and Dyson HJ (1999). Intrinsically unstructured proteins: re-assessing the protein structure-function paradigm. J. Mol. Biol. 293: 321-331. http://dx.doi.org/10.1006/jmbi.1999.3110

Yamada MM, Bartley BGD, Castro GCT and Melo GRP (1982). Heredity of comparable factor in Theobroma cacao L. I. Phenotypic relations in family $\mathrm{Pa}$ (Parinari). Theobroma 12: 163-167.

Zhang L, Ma X-L, Zhang Q, Ma C-L, et al. (2001). Expressed sequence tags from a NaCl-treated Suaeda salsa cDNA library. Gene 267: 193-200. http://dx.doi.org/10.1016/S0378-1119(01)00403-6 